\title{
The Revival of Studies
}

\section{on Wenxin Diaolong after the Cultural Revolution: the Contribution of Some Scholars}

\section{文革後關於《文心雕龍》相關研究的復興:一些學者的貢獻}

\author{
Alessandra C. Lavagnino 蘭珊德
}

DoI: http://dx.doi.org/10.7359/825-2017-lav2

\begin{abstract}
This contribution will look back to the turning point at the end of the 70's when, in Mainland China, studies on Wenxin diaolong started to be published or re-published. I was in Shanghai in those years (1977-79) and I had the good fortune to know personally some of the heroic scholars whose work was fundamental to the revival of the research on Wenxin diaolong. They had the courage and generosity to share their profound knowledge and experience with young scholars, at a time when the study of, and research in Classical Chinese were still a sensitive matter. They promoted the publication of essays, critical editions and modern translations of the text. The paper will therefore focus on an account of this period and on a description of the most significant texts published in those years. Retracing this path could now be helpful to a deeper understanding of the revival of research on Wenxin diaolong, of the birth of The Chinese Wenxin Dialong Association (Zhongguo Wenxin diaolong xuebui 中國《文心雕龍》學會) in 1983, and of the development of the Dragonology (longxue龍學) in and outside China. Compared to the numerous and well documented research which was later carried out, the value and quality of the contributions which were published in the early years after 1978 bear witness the great courage needed to take on a difficult topic, at a time when Chinese intellectuals were gradually emerging from the most
\end{abstract}


difficult (the hardest/toughest years), drawing on their own profound knowledge of classical Chinese culture, that is to say (and in doing so) rediscovering their deepest roots. They were mostly intellectuals of a certain age who during the Cultural Revolution had been criticized, sent to the countryside to do hard labor, and obliged to humiliate themselves by bowing to the regime. Now courageously they were retrieving the meaning of the "predominance of Confucian knowledge". Only a few years back Confucius had been the victim of a so called "mass-movement", which was heavily orchestrated by political propaganda, and which lasted for almost two years. In the eyes of the average Chinese person at that time - and also in the minds of the ignorant Red Guards - Confucius was still seen as the "philosopher of the reactionary class". Wang Yuanbua be ta de pengyoumen 王元化和他的朋友 (Wang Yuanhua and His Friends) - a book with this title has been published in China remembering these crucial moments (Luo 2009) - had the courage to go against the tide and return to their studies. At that time, they still couldn't make independent use of the results of international academic research because they simply were not yet allowed to have direct contact with intellectuals and scholars from abroad. This contact gradually happened throughout the eighties, and increasingly from the beginning of the '90s. These elderly scholars had no other option than to rely on their own knowledge and stick to the traditional Chinese academic tools such as reading and re-reading a text, interpreting and rediscovering the intertextual connections in the boundless heritage of the traditional literature. The mutual understanding which resulted from this gave them an awareness of their belonging to a common cultural élite. They were not only specialists of one single topic, as is now the case in the academic world, but rather they were intellectuals, men of great classical culture who in many cases did not concentrate their studies exclusively on a single topic of research, an author, on a specific historical period, but among themselves (together / in each other's company) savored (xingshan 欣賞) and appreciated reading and interpreting a literary work as a part of a process of acquiring greater knowledge. This is exemplified by the role played by Zhang Guannian 張光年, a famous writer, and a poet who became the first President of The Chinese Wenxin Diaolong Association. Thus, the sheer pleasure of reading a literary work which had been forbidden for such a long time, became once again for this group of intellectuals a way of acknowledging that their own cultural identity had survived the terrible events of the China of those years. And this identity was rooted precisely in China's classical past, the understanding and awareness of which had been denied to the younger Chinese. And this plaisir $d u$ text generated a new hope for the future.

Keywords: Wenxin diaolong, (after the) Cultural Revolution, revival of research, cultural identity, China’s classical past. 
摘要

這一貢獻可追溯回70年代末期的一個轉捩點, 當時, 中國大陸關於《文心雕龍》的文章開 始發表或者重新被發表。那幾年, 我在上海(1977-79), 我很幸運地認識了一些對《文心 雕龍》的研究和復興起到至關重要作用的傑出的學者。他們慷慨、英勇地與年輕的學者們 分享他們淵博的學識和豐富的經驗。而在當時, 中國古典文學的研究仍是一個敏感話題, 也正是他們促進了相關論文、評述版和現代譯本的出版。因此，本文將重點介紹這一時期， 並描述這一時期發表的重要的文獻資料。通過回顧這一歷史時期, 有助於更深入地瞭解、 研究《文心雕龍》的復興, 如1983年成立的文心雕龍學會以及龍學在中國國內及國外的發展。 與後來所做的大量有據可查的文獻研究相比, 1978年以後發表的論文數量和價值證明了研 究這樣一個艱難的課題需要巨大的勇氣。那時, 中國的知識份子正在逐漸擺脫最艱難的時 期, 利用自己淵博的中國古典文學知識重新找回他們最深的根基。他們大多是中年的知識 份子, 在文革時期受到批判, 被送往鄉下從事艱苦勞動, 被迫向政權低頭。現在他們勇敢 地找回了 “儒家知識的主導地位”。就在幾年前, 孔子曾是一場所謂群眾運動的受害者, 這場運動是由政治宣傳機構精心策劃的，持續了將近兩年。在當時的中國人的眼中，在無 知的紅衛兵的心目中一孔子仍被視為 “反動階級的哲學家” 《《王元化和他的朋友們》一 書已經在中國出版, 用於記住那些重要的時刻一有勇氣逆潮流而去, 回到他們的研究中 去。那時, 他們還不能獨立使用國際學術研究成果, 因為他們不允許與國外知識份子和學 者直接接觸。從 80 年代逐漸允許他們接觸, 90年代開始變得越來越頻繁。這些上了年紀的 學者除了依靠自己的知識外, 沒有其他選擇, 只能依靠傳統的中國學術工具, 如閱讀或重 讀一篇文章。在傳統文學的廣闊海洋中, 闡釋並重新找到文本之間的聯繫。由此相互理 解, 使他們意識到他們共屬同一文化。他們不只是某一單一課題的專家, 他們也是偉大的 中國古典文化的學者, 像現在學術界的情況一樣, 他們在很多情況下並沒有將他們的研究 完全集中在單一的課題上。一個作家，在特定的歷史時期，都將欣賞、閲讀和理解文學作 品作為獲取更多知識的過程的一部分。如著名的作家、詩人, 文心雕龍協會的首位主席, 張光年先生。因此, 閱讀一部被禁了很久的文學作品的純粹樂趣, 再次成為這些知識份子 的一種方式，一種承認他們自身文化身份在這些年來的可怕事件中倖存下來的方式。而這 種身份恰恰植根於中國的古典歷史, 而這卻不被中國年輕一代所理解和認識。正是這篇文 章為未來帶來了新的希望。

關鍵詞：《文心雕龍》, 文革後, 研究的復興, 文化身份, 中國的古典歷史。

\section{FOREWORD}

Among the many changes that had taken place in China after Mao's death, one of the most significant was certainly that one involving the intellectual and academic world: a world that during the years of the Cultural Revolution had been subjected to harsh debates and clashes and unprecedented violence. The present contribution retraces a little portion - the resumption of studies on Wenxin diaolong 文心雕龍 (hencefor- 
ward, WXDL $)^{1}$ - of an important moment that the Chinese academic world crossed in the early years following the death of Mao. My aim is to add just a "little brick" to rebuild not only the memory of a period which was crucial to the development of subsequent academic studies, but also to bear witness to the vitality and passion for the research in China in those years.

The idea of proposing, about forty years later, a reflection on this subject was prompted by an invitation by some young French colleagues to participate in a panel dedicated to WXDL entitled "Uncarving the Dragon: Retrospective and Prospective on Wen xin diao long" during the XIX Congress of the European Association for Chinese Studies held in Paris in September 2012 (Guiheux, Lamarre, and Suchet 2012). The unexpected invitation became thus the occasion to return after many years to a subject, which in the past had been the focus of years of research that I conducted largely in China since 1978. With the present contribution, I would like to make a further excursion into the academic and cultural atmosphere of those years to share with colleagues some reflections on the extraordinary work done by some eminent Chinese scholars, and some ideas that come directly from the memories of those years. I hope in this way to provide a useful tool to better contextualize the development of a major academic topic that still today, especially in China, is articulated in an original richness of contributions.

\section{1978: THE BEGINNING}

I will start with a short personal memory. I was in Shanghai in the Autumn of 1978: it was my second stay in China as a Foreign Expert (waiguo zbuangjia 外國專家), at what was then the Shanghai Foreign Languages Institute (Shanghai waiguoyu xueyuan 上海外國語學院), now Shanghai International Studies University (SISU).

I taught Italian Language and Culture there, and whereas during my previous stay (from the beginning of 1974 to the end of 1975) I hadn't been allowed to study Classical Chinese - I had graduated from Rome University with a degree in Classical Chinese Studies - this time I was

1 For further discussion on the many possibilities of translating the title, refer to my other contribution (pp. 9-24). 
able to. The University provided me with a teacher two afternoons a week, who made me read and learn selected passages from the celebrated Guwen guanzhi 古文觀止. Having obtained this permission was indeed a concrete sign of a new trend, a new development and not an obvious event because, when I had been in Shanghai two years before, the Cultural Revolution was still going on and studying Classical Chinese was strictly forbidden, not only for me but also for Chinese students: only the stereotyped slogans of pilin pikong 批林批孔 were allowed in those difficult years ...

During my lessons, then, my Chinese teacher introduced me to some chapters from WXDL, the obvious choice being chapt. I, Yuandao 原道 and chapt. XXVI, Shen si 神思 ${ }^{2}$. And I was enchanted! I immediately went to the bookshop - the huge New China Bookshop in Nanjing Road, which today has become a large Department Store, selling electronic goods and high street clothes ...- - and there I found, fresh from the press, the Wenxin diaolong zhu 文心雕龍註: the text of WXDL with precious notes and comments by Fan Wenlan 范文瀾, which was first published in 1958 and republished then, in 1978, in non-simplified characters (Fan [1958] 1978)! This struck me at the time as a proof of enormous courage in a moment when the heritage of the past was still far away of being properly appreciated and the publications in non-simplified characters were almost forbidden.

I threw myself into this extremely difficult work, with the indispensable help of my Chinese colleagues of the Department of Chinese. They were mostly old men, who for twenty years had been forced to wear the infamous "hat" of "rightist" and who had just been recalled to their position. In order to really understand this atmosphere, it is worth to remember that between March '77 and December '78, about 2 million cadres were rehabilitated. They had been accused of being "followers of the capitalistic road” (zouzipai 走資派). There were also 552.877 (more than half a million) “right-wing elements" (youpaifenzi 右派分子), who at the end of the 50's had been thrown out of the party, and were at that time allowed to have their political rights back and resume a normal life. And more than four million four thousand were the "landlords, rich peasants, counter revolutionaries, and bad elements", according to the orthodox Maoist classifications in use at the beginning of the PRC. Their "original sin"

2 For the various translations of chapters titles, see Simona Gallo's contribution (pp. 99-113). 
being their class origin, or political status, which for years had discriminated entire families and clans, was finally cancelled (Lavagnino 2014).

And here they are, now, timidly making their way into my office, the only one which had the privilege of having a little stove against the freezing Shanghai wintertime. They came to read WXDL with me and to explain and translate it to me into colloquial Chinese: for me they wrote notes and comments on paper which was almost transparent, which were then handed to me by ageing librarians, from friends of friends, who, after the initial shock, used the "young lady with big nose" as a nice excuse to return with increasing courage to topics which up until a few months earlier had been taboo. Now, once again, they could leaf through volumes which, if they hadn't been burnt during the Cultural Revolution, had not been available because they were simply forbidden, considered examples of "feudal thinking" or "poisonous weeds".

A volume, published in 2001, compiled by prof. Zhang Shaokang and other colleagues from Beijing University (Wenxin diaolong yanjiu lishi 文心雕龍研究歷史) (Zhang et al. 2001), lists and describes the articles on this subject which were published in the few Chinese Journals authorized by the Party in those difficult years.

As we can see from the chart I have prepared from the data of Zhang Shaokang's volume, no research whatsoever was done in those years. We can see the number of articles in Chinese published per year - from 1964 to 1983 - on our topic in Mainland China (A) and in Korea, Japan, Taiwan, Hong Kong (B) (Tab. 1) ${ }^{3}$.

As we can see, the number of articles published in Mainland China in those years was very scarce, and the contents were all extremely negative about the value itself of WXDL, considered as a feudal and reactionary text. Those articles not only had no academic value, but were only used as tools in the political struggle.

This is the case of articles published in 1974, in the only one printed in 1975, three in 1976. From 1977 the trend started to change, the quantity of contributions published increased and contents were slowly shifted from the simple slogans of the Cultural Revolution to a more and more complex and diversified scope (Zhang et al. 2001, $323 \mathrm{ff}$.).

3 This chart is limited to 1983, the year of the founding of The Chinese WXDL Association. See also Wang 2011. 
Table 1.

\begin{tabular}{ccc}
\hline YEAR & A & B \\
\hline 1964 & 11 & 5 \\
1965 & - & 3 \\
1966 & 1 & 5 \\
1967 & - & 12 \\
1968 & 1 & 12 \\
1969 & 2 & 13 \\
1970 & - & 27 \\
1971 & - & 21 \\
1972 & - & 13 \\
1973 & - & 19 \\
1974 & 6 & 15 \\
1975 & 1 & 26 \\
1976 & 3 & 33 \\
1977 & 20 & 22 \\
1978 & 2 & 25 \\
1979 & 57 & 11 \\
1980 & 66 & 32 \\
1981 & 82 & 14 \\
1982 & 34 & 14 \\
1983 & 156 & 19 \\
\hline
\end{tabular}

It was only with hindsight that we realized the fundamental importance, even in the academic world - of the date of the 17th December 1978. That was the day on which the Third Plenum of the XI Central Committee of CCP was held, which endorsed the beginning of the new era of gaige kaifang 改革開放 (reform and opening), the policy launched by Deng Xiaoping. In Shanghai, were I was at the time, the first publications that interested us were soon on the shelves.

\section{Lu KANRU 陸㑆如 AND Mou SHIJIN 牟世金}

The first tiny volume I bought in Shanghai in 1978 is part of a collection which at the time was very popular: "Collection of Basic Knowledge of Ancient China" (Zhongguo gudianwenxue jiben zhishi congshu 
中國古典文學基本知識叢書). This was, in fact, one of the few series about ancient China of which the publication was not banned. We should remember that during the pilin pikong 批林批孔 movement, three years previously, the official purpose for studying classical Chinese was to criticize "feudal ideas and reactionary thinkers", and no courses on Classical Chinese were allowed all over the country.

The Collection was described as follows on the back cover of each volume:

This series wants to provide basic knowledge of classical China to readers with an average standard of education. These books consist of basic knowledge of the works of writers who have in some ways influenced the history of Chinese literature, the main movements, and literary schools, literary genres and forms. The editors have done their best to express the correct position, to provide exhaustive contents, describe in a straightforward way the necessary things, with characters which are easy to understand and commonly used. Because of the limits of our level, it has been difficult to avoid mistakes. We hope that our readers will make their criticisms and correct us.

這套叢書是向中等以上文化程度的讀者介紹中國古典文學的基本知識, 內容包括文學史上 比較有影響的作家和作品, 重要的文學活動和文學流派, 以及文學體裁方面的基本知識。 叢書的編寫力求觀點正確, 內容充實, 叔述簡明扼要, 文字通俗易懂。由於我們水準有限, 工作中難免有缺點錯誤, 希望讀者批評指正。(Lu and Mou 1978)

The title of the book is Liu Xie be Wenxin Diaolong 刘锶和文心雕龍 (Lu and Mou 1978). There are only 76 pages; it is a thin volume, but the authors, Lu Kanru and Mou Shijin are important. Lu Kanru 陸㑆如 (1903-1978), was an eminent scholar of classical Chinese poetry. In the Thirties he studied with his wife, Feng Yuanjun 馮沅君, in France, at Paris University, where he translated the works of Bernhard Karlgren into Chinese, and together with his wife wrote a History of Chinese Poetry. In the Fifties, he was labelled as "rightist" ${ }^{4}$. When he was teaching at Shandong University, Mou Shijin 牟世金 (1928-1989) was his student and followed in his academic footsteps. Mou was politically more trustworthy: according to his biography, he was a party member ${ }^{5}$.

Together they published a few articles and essays on WXDL before the Cultural Revolution, among them, the Wenxin diaolong xuanyi

4 http://www.baike.com/wiki/陆㑆如.

5 http://www.baike.com/wiki/牟世金. 
文心雕龍選譯 (Lu and Mou 1962; 1963) and in 1963 Liu Xie lun cbuanzuo

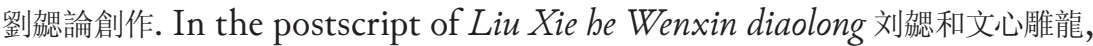
the authors declared:

The book is an old draft written before the Cultural Revolution and now, apart from a few small changes, such as Bixing [chapt. XXXVI] which was included into the same chapter of Zongshu [chapt. XLIV] and has now become an independent paragraph, a few misprints have been corrected. Obviously, there are going to be mistakes, which we hope our readers will correct.

附記

此書是我們在文化大革命前寫的舊稿。這次除了把原來在 “總術” 問題中附論的 “比興” 問題移出, 擴大稱為一小節外, 其餘只做了個別比要的修改。不當之處一定不少, 切望得到 讀者指正。(Lu and Mou 1978, 155)

"In a straightforward way" and "with characters which are easy to understand and commonly used" as it was clearly requested and it was the hallmark of the Editors of the series, the authors described in a clear and well-organized way the main characteristics of the work. They started by giving an essential explanation of the historical and literary context, a brief biography of the author, and an account of the literary theory before the age of Liu Xie.

Obviously, their conclusion cannot avoid the mandatory tribute to the current ideology:

Today under the guide of the principle "Make the past serve the present" we want to have a reasonably correct understanding of WXDL, we must adopt the method of Marxist historicism and class analysis to take what we need from this book. We have to study intensively this masterpiece and carefully distinguish what is good from what is bad, and critically inherit it. Liu Xie was a servant of the dominant feudal class and he judged literature from the point of view of Confucian Literati. His critical standards were heavily colored by feudalism ... He underlined the talent and the nature of each writer, and he did not understand their class nature.

今天, 我們在 “古為今用” 的原則指導下, 要對 “文心雕龍” 獲得一個比較正確的認識, 從 中有所借鑒, 就應該正確運用馬克思主義的歷史主義和階級分析的方法, 認真鑽就這部 傑作, 細絰地分辨其中的精華和糟粕加以批判地繼承。他為封建統治階級服務, 並用儒家 觀點來衡量作品。他的批評表准有濃厚的封建色彩。他強調作家的才華和性情, 而不懂得 作家的階級性。(Lu and Mou 1978) 
As we said, this is a mandatory tribute which has obviously to repeat repeats the ideological tones of the propaganda, and which today sounds naive and sad, mostly because we all know the academic standing of these two scholars. But this tribute is a proof of the oppressive atmosphere in which the Chinese intellectuals were living in those years, and it also shows the political price that they had to pay daily to negotiate even the smallest amount of freedom for their research.

When his teacher died, Mou Shijin took the work in hand and continued it. It was published in both their names the volume Wenxin diaolong yi zhu 文心雕龍譯註 (the first volume was published in 1981 and the second in 1982, in 1995 it was reprinted in one volume) (Lu and Mou [1981-1982] 1995). The first volume contains 114 pages of "Introduction" which is not signed - according to the customs of the time - but as the date is 1980 and Lu Kanru died in 1978, it is obviously written by Mou Shijin. The introduction has 136 extensive bibliographical notes, which was a rarity for the time, and is divided into 6 sections:

1. "The historical conditions which produced WXDL";

2. "Life and thought of Liu Xie";

3. "General theory, and theoretical system of WXDL";

4. "Poetry and prose, summing up the experience of his predecessors";

5. "On creation";

6. "On criticism".

Each chapter is preceded by a brief explanatory introduction, the text of Liu Xie is divided into short passages - written in simplified characters -, has got ( $z h u$ 註) textual notes, and an yiwen 譯文, an intralingual translation in contemporary Chinese, which is easy to understand and clear. At the end of the second volume, there is an extensive bibliography of the works quoted, a practice that at that time was quite unusual. Mou Shijin carried on the work of his teacher and became one of the main initiators of The Chinese WXDL Association, which was officially established in 1983. In that year, he published a collection of his essays in a volume entitled Diao long ji 雕龍記 (Mou 1983).

His early death, in 1989, was a source of great sadness to his colleagues, who remembered him with great affection, and his academic contribution with great admiration. Thus, he is remembered by Wang Yuanhua, who wrote the "Preface" to his posthumous collection Wenxin diaolong yanjiu 文心雕龍研究 (Mou 1995). Wang Yuanhua wrote an early "Preface" in 1988, before the death of Mou Shijin, and updated it in 1990. 
The volume has also a "Preface" written in 1988 by Mou himself, who said that because 1988 was a year of the Dragon, he felt that he wanted to write about dragons.

We will describe Wang Yuanhua's contribution in details in the following pages.

I would like first to briefly describe the work of two more authors. They are important for our topic because in those crucial years, the Eighties, they were finally able to resume their studies on WXDL and circulate the results of their research once again.

\section{Zhou Zhenfu 周振甫}

Zhou Zhenfu 周振甫 (1911-2000) didn't have an academic career at University, but was a man of letters, active in literary circles, friend and colleague of celebrated scholars as Qian Zhongshu 錢鐘書. He was at first editor at the Kaiming shudian in Shanghai, and then he moved to the prestigious Zhonghua shuju 中華書局 ${ }^{6}$. He is the author of ten volumes of essays on important authors of traditional Chinese literature and thought.

Zhou Zhenfu wrote some essays on WXDL before the Cultural Revolution, but for our purpose is interesting to point out that in 1980 he published a volume which is very helpful for a Chinese reader who is approaching this masterpiece for the first time. The volume, Wenxin diaolong xuanyi 文心雕龍選譯 (Zhou 1980), has a very useful selection of chapters.

In this publication, Zhou Zhenfu only selected 35 chapters. He didn't include chapt. IV (Zheng Wei 正緯), which can most easily be associated with topics which at that time were still labelled as mixin 迷信 (superstition), like prodigies, omens, and apocryphal texts ... He traces a biography of Liu Xie, and puts the last chapter (Xuzhi 序志) at the beginning of the volume, followed by the 34 chapters of his selection. The original text of each chapter is preceded by a brief explanation written in accessible and easy language by Zhou himself, and then the text is divided into passages followed by a translation into colloquial Chinese, with brief explanatory notes. No references are made to sources and bibliography (Zhou 1980).

The same didactic purpose is evident in his publication the following year, which is entitled Wenxin diaolong zhushi 文心雕龍注釋 (Zhou 1981). Here he reproduces the whole text of WXDL, each chapter has a brief

6 http://xbsh.net/author/1410.html. 
ping 評, as introductory comment, the notes are very extensive, at the end of each chapter there is a shuoming 說明, which is very clear and straightforward.

We should also mention Zhou's Wenxin diaolong jinyi 文心雕龍今譯 (Zhou 1986): preceded by a concise biography of Liu Xie, all the chapters are reproduced according to the original order, and Xuzbi 序志 comes at the end. Each chapter is provided with a brief introduction, then the original text is divided into passages, accompanied by notes and by an extremely clear translation in contemporary Chinese. It comes with a “Brief glossary” (ciyu jianshi 詞語簡釋, 455-542), organized by stroke order.

This part of the volume was to become core of the "Dictionary of WXDL” (Wenxin diaolong cidian 文心雕龍詞典) that Zhou published ten years later (Zhou 1996).

It is worth to mention that the 1986 volume became the one which was used by Yang Guobing for his translation into English, published in 2003 (Yang 2003).

\section{YANG MingZHAO 楊明照}

Another important scholar whose works started to be available again at the beginning of the Eighties was Yang Mingzhao 楊明照 (1909-2003), who back in 1939, when he was only thirty, had wrote Wenxin diaolong jiaozhu 文心雕龍校注 (Yang 1958), a contribution that Hong Kong's important newspaper Dagongbao 大公報 had acclaimed at the time as a milestone in the studies on WXDL, and which in Mainland China was considered a real Encyclopedia on WXDL. After the years of forced silence during the Cultural Revolution, he resumed his research and in 1978 became the Head of the Department of Chinese at Sichuan University ${ }^{7}$. The breadth of his research is impressive (Yang et al. 1995; Yang 2008), as we can see from the vast biobibliography recorded by the Chinese academy.

In 1982 the prestigious Shanghai Guji shudian 上海古籍書店 republished his revised edition of the text he wrote in 1939, entitled Wenxin diaolong jiaozhu shiyi文心雕龍校注拾遺 (Yang 1982). The decision to print such a challenging work, which is of a considerable academic depth and difficulty, shows us that the intellectual and publishing world at that time were deeply concerned to raise the level of studies related to classical

7 http://www.guoxue.com/rw/yangmingzhao/ymz01.htm. 
Chinese literature. They no longer wanted to limit themselves to publishing things that were accessible to a wide reading public, "easy to understand and politically correct", as we have just seen it was the case in the previous years. Their concern was now to publish works which were more academically demanding, grounded in a solid basis of classical tradition. And to overcome the ten years of darkness in the classical Chinese training, they were almost obliged to go back to a masterpiece published forty years earlier. I don't need to add anything more about Yang Mingzhao's vast range of knowledge and numerous publications. But I would just like to say that I knew him personally when I had the honor to be invited to participate at the III Conference of The Chinese WXDL Association, which was held in Guangzhou in the Autumn of 1988. And it happened to be that he was the kind and attentive Chairman of the Session where, overcome with emotion, I presented my paper (Lavagnino 1989).

\section{Wang Yuanhua 王元化}

I would like to close this brief panorama of this crucial period by devoting a few words to somebody who - to my mind - represents the ideal Chinese intellectual, who lived through the suffering and hardship of the dramatic years of XX century's China with great dignity, intelligence and courage. The person who I am referring to is Wang Yuanhua 王元化 (1920-2008), and I was honored by his friendship.

He had been a member of CCP since 1938, he toed the party line following the literary enthusiasms for Russian literature, but he also paid a heavy price for his commitment to the political struggle. In fact, in 1955 he was involved in the "Hu Feng case", and he was only rehabilitated in 1981. This meant only at the beginning of the eighties was he able to hold public office again. He then became a Professor at Fudan University, member of distinguished institutions and distinguished counselor and friend of Wang Daohan 汪道涵 ${ }^{8}$, the first Shanghai Municipality Major after the fall of the Gang of Four ${ }^{9}$.

8 http://zh.wikipedia.org/wiki/汪道涵.

9 For more details on the biography and works of Wang Yuanhua, see Ma 2008; Liu 2009; Lu 2009; Luo 2009. See also “Wang Yuanhua”: http://www.guoxue.com/ rw/wangyuanhua/wyh01.htm. 
His first work on WXDL, Wenxin diaolong cbuangzuolun 文心雕龍創作論 (Wang 1979), was published in 1979, but, as the author himself admits, it was written in 1966. Obviously at that time he could not publish it. This text is divided in two parts: the author, Liu Xie, the period in which he lived, his literary theory, and a choice of eight chapters which are discussed in detail. In the second edition (Wang [1979] 1984), the original text is republished in fantizi 繁体字, it contains a more detailed apparatus criticus and an "Appendix", which was further corrected and republished (Wang [1984] 1992). This contribution is unanimously recognized as a masterpiece of critical analysis.

In the first years of the Eighties, Wang Yuanhua also became a leading figure in the New Enlightment Movement (xin qimeng 新启蒙), a source of inspiration for the hopes and expectations of Chinese intellectual whose main concern was a more open cultural policy that China should adopt.

Thus, in 1983 The Chinese WXDL Association was founded. It gathered together scholars, most of whom were of a certain age. Initially they were only Chinese from Mainland China, but soon the Association included scholars from Hong Kong and Taiwan and a few foreigners, such as South Koreans, and Japanese who during the years of the Cultural Revolution contributed to keeping the studies on WXDL alive. We Europeans joined the Association later, in 1988. This was the beginning of an international academic community: materials and documents started to be exchanged cautiously among the various scholars. Thanks to the acknowledged academic prestige and a remarkable ability to communicate, Wang Yuanhua will soon become one of the main ambassadors of the international academic community, carrying out an irreplaceable work to foster a genuine openness of the Chinese academic environment to colleagues from other countries. And yet again is thanks to Wang Yuanhua that Chinese scholars discovered the extent of the work done by Japanese sinologists on WXDL (Wang 1983).

\section{Conclusions}

Compared to the valuable, extensive and well documented research which was done later on, the value and quality of the contributions which were published in the early years after 1978 bear witness to the great courage needed to take on a difficult topic, at a time when Chinese intellectuals 
were gradually emerging from the toughest years, drawing on their own profound knowledge of classical Chinese culture, and rediscovering their deepest roots.

They were mostly intellectuals of a certain age who during the Cultural Revolution had been criticized, sent to the countryside to do hard labor, and obliged to humiliate themselves by bowing to the regime. Now courageously they were retrieving the meaning of the "predominance of Confucian knowledge". Only a few years back Confucius had been the victim of a so called "mass-movement" which was heavily orchestrated by political propaganda, and which had lasted for almost two years. In the eyes of the average Chinese person at that time - and also in the minds of the ignorant Red Guards - Confucius was still seen as the "philosopher of the reactionary class".

Wang Yuanbua he ta de pengyoumen 王元化和他的朋友 (Wang Yuanhua and His Friends) - a book with this title has been published in China remembering these crucial moments (Luo 2009) - had the courage to go against the tide and go back (return) to their studies.

At that time, they still couldn't make independent use of the results of international academic research because they simply were not yet allowed to have direct contact with intellectuals and scholars from abroad. This contact gradually happened throughout the Eighties, and increasingly so from the beginning of the '90s.

These elderly scholars had no other option than to rely on their own knowledge and stick to the traditional Chinese academic tools such as reading and re-reading a text, interpreting and rediscovering the intertextual connections in the boundless heritage of the traditional literature. The mutual understanding which resulted from this, gave them an awareness of their belonging to a common cultural élite. They were not only specialists of one single topic, as is now the case in the academic world, but rather they were intellectuals, men of great classical culture who in many cases did not concentrate their studies exclusively on a single topic of research, author, or a specific historical period, but among themselves (together / in each other's company) savored (xingshan 欣賞) and appreciated reading and interpreting a work of literature as a part of a process of acquiring greater knowledge. This is exemplified by the role played by Zhang Guannian 張光年, a famous writer, and a poet who became the first President of The Chinese WXDL Association.

Thus, the sheer pleasure of reading a work of literature, which had been forbidden for such a long time, became once again for this group 
of intellectuals a way of acknowledging that their own cultural identity had survived the terrible events of the China of those years. And this identity was rooted precisely in China's classical past, the understanding and awareness of which had been denied to the younger Chinese.

And was this plaisir du text which generated a new hope for the future.

\section{REFERENCES}

Guiheux, Gilles, Christine Lamarre, and Soline Suchet, eds. XIXth EACS Conference. Paris. 5-8 September. Book of Abstracts. Paris: Université Paris Diderot INALCO - BULAC.

Lavagnino, Alessandra C. 1989. "Il Congresso internazionale di studi sul Wenxin diaolong. Canton, novembre 1988”. Culture 4: 169-177.

Lavagnino, Alessandra C. 2014. "Il contributo di alcuni eminenti studiosi cinesi alla rinascita degli studi sul Wen xin diao long dopo la Rivoluzione Culturale”. In Il liuto e i libri. Studi in onore di Mario Sabattini, a cura di Magda Abbiati e Federico Greselin, 467-482. Venezia: Cafoscarina.

Liu Ling. 2009. "Wang Yuanhua 'guilu' fansi yu Wenxin diaolong chuangzuolun jianfa shi xiuding” 王元化 “規律” 反思與 《文心雕龍創作論》 “減法” 式修訂 (Wang Yuanhua reflection on the 'norms' and revision of the 'subtraction' rule in On creation in Wenxin diaolong). Wenxin diaolong yanjiu 文心雕龍研究 8: 9-28.

Liu Xie. 2003. Dragon-Carving and the Literary Mind. Beijing: Foreign Language Teaching and Research Press [Eng. transl. Yang Guobin].

Liu Xie, Fan Wenlan, ed. (1958) 1978. Wen xin diao long zbu 文心雕龙註 (Annotated edition of Wenxin diaolong). Beijing: Renmin wenxue.

Liu Xie, Yang Mingzhao, ed. 1958. Wenxin diaolong jiaozhu 文心雕龍校注 (Revised annotated edition of Wenxin diaolong). Shanghai: Gudian wenxue chubanshe.

Liu Xie, Yang Mingzhao, ed. 1982. Wenxin diaolong jiaozbu sbiyi 文心雕龍校注拾遺 (Additions to the annotated version of Wenxin diaolong). Reprint, Shanghai: Guji chubanshe.

Liu Xie, Zhou Zhenfu, ed. 1986. Wenxin diaolong jinyi 文心雕龍今譯. Beijing: Zhonghua shuju.

Lu Kanru and Feng Yuanjun. 1956. Zhongguo shishi 中国诗史 (History of Chinese Poetry). Beijing: Renmin chubanshe.

Lu Kanru and Mou Shijin. 1962. Wenxin diaolong xuanyi. Shang ce 文心雕龍選譯上冊 (Selection from Wenxin diaolong. Volume I). Jinan: Shandong Renmin chubanshe. 
Lu Kanru and Mou Shijin. 1963a. Wenxin diaolong xuanyi. Xia ce 文心雕龍選譯下冊 (Selection from Wenxin diaolong. Volume II). Jinan: Shandong Renmin chubanshe.

Lu Kanru and Mou Shijin. 1963b. Liu Xie lun cbuanzuo 劉势論創作. Hefei: Anhui Renmin chubanshe.

Lu Kanru and Mou Shijin. (1963) 1982. Liu Xie lun cbuanzuo. Xiuding ben 劉諰論創作: 修訂本 (On Liu Xie and literary creation. Revised edition). Hefei: Anhui Renmin chubanshe.

Lu Kanru and Mou Shijin. 1978. Liu Xie be Wenxin diaolong 劉睤和文心雕龍 (Liu Xie and Wenxin diaolong). Shanghai: Shanghai guji chubanshe.

Lu Kanru and Mou Shijin, eds. 1981-1982. Wenxin diaolong yi zbu 文心雕龍譯註 (Translations and notes to Wenxin diaolong). Jinan: Shandong renmin chubanshe.

Lu Kanru and Mou Shijin, eds. (1981-1982) 1995. Wenxin diaolong yi zhu 文心雕龍譯註. Reprint, Jinan: Jinan: Qi Lu shushe.

Lu Shaoguang. 2009. "Wang Yuanhua Wenxin diaolong yanjiu - you qingzhi you lixiangdexueshu” 王元化的文心雕龍研究一有情志有理想的學術 (Wang Yuanhua's research on Wenxin diaolong - a passionate ad ideal academic knowledge). In Wenxin diaolong yu 21 shiji wenlun yanjiu 《文心雕龍》與21世紀文論研, edited by Zhongguo Wenxin diaolong xuehui 中國《文心雕龍》學會, 1-13. Beijing: Xuefan chubanshe.

Luo Yinsheng. 2009. Wang Yuanbua be ta de pengyoumen 王元化和他的朋友們 (Wang Yuanhua and his friends). Changsha: Hubei renmin chubanshe.

Mou Shijin. 1983. Diao long ji 雕龍記 (Notes on dragon-carving). Beijing: Zhongguo shehui kexue chubanshe.

Mou Shijin. 1995. Wenxin diaolong yanjiu 文心雕龍研究 (Research on Wenxin diaolong). Beijing: Renmin wenxue chubanshe.

Wang Yanhua. 1979. Wenxin diaolong chuangzuolun 文心雕龍創作論 (On creation in Wenxin diaolong). Shanghai: Guji chubanshe.

Wang Yanhua. (1979) 1984. Wenxin diaolong cbuangzuolun 文心雕龍創作論 (On creation in Wenxin diaolong). Reprint, Shanghai: Guji chubanshe.

Wang Yanhua. 1983. "Wang Yuanhua xuanbian, Riben yanjiu Wenxin diaolong lunwen ji” 王元化選編: “日本研究“文心雕龍”論文集” (Essays on Japanese researches on Wenxin diaolong), selected and edited by Wang Yuanhua. Jinan: Jilu shushe.

Wang Yanhua. (1984) 1992. Wenxin diaolong jiangshu 文心雕龍講疏 (Comments and annotations to Wenxin diaolong). Reprint, Shanghai: Guji chubanshe.

Wang Yanhua. 2011. "Zhongguo dalu jinwushinian (1949-2000) Wenxin diaolong xueshu yanjiu gaiguan” 中國大陸近五十年(1949-2000)文心雕龍學術研究概觀（An objective regard on academic researches carried on in Mainland China in the last (1949-2000) fifty years). In Zhongguo Wenxin diaolong yanjiu 中國文心雕龍研究, 
edited by Zhongguo Wenxin diaolong xuehui 中國《文心雕龍》學會, 58-103. Beijing: Hebei daxue chubanshe.

Yang Mingzhao. 2008. Lun Wenxin diaolong 論文心雕龍 (On Wenxin diaolong). Shanghai: Kexue jishu wenxian chubanshe.

Yang Mingzhao et al., eds. 1995. Wenxin diaolong xue zonglan 文心雕龍學綜攬 (Compendium of studies on Wenxin diaolong). Shanghai: Shanghai shudian chubanshe.

Zhang Shaokang, Wang Chuhong, Chen Yunfeng, and Tao Litian. 2001. Wenxin diaolong yanjiu lishi 文心雕龍研究歷史 (History of the research on Wenxin diaolong). Beijing: Beijing daxue chubanshe.

Zhou Zhenfu. 1980. Wenxin diaolong xuanyi 文心雕龍選譯 (Wenxin diaolong selected traslations). Beijing: Zhonghua shuju.

Zhou Zhenfu. 1981. Wenxin diaolong zhushi 文心雕龍注釋 (Notes and comments to Wenxin diaolong). Beijing: Renmin wenxue chubanshe.

Zhou Zhenfu. 1986. Wenxin diaolong jinyi 文心雕龍今譯 (Modern version of Wenxin diaolong). Beijing: Zhonghua shuju.

Zhou Zhenfu. 1996. Wenxin diaolong cidian 文心雕龍詞典 (Wenxin diaolong dictionary). Beijing: Zhonghua shuju.

\section{WEB REFERENCES}

Lu Kanru. http://www.baike.com/wiki/陆㑆如. Last modified 30 October 2017.

Ma Guochuan. 2008. “Wang Yuanhua: zuihoude fangtan” 王元化最後的訪談 (Wang Yuanhua: the latest interview). Last modified 30 September 2017. [30.09.2017]. http://www.eeo.com.cn/2008/0516/100071.shtml

“Mou Shijin”. Last modified 30 September 2017. [30.09.2017]. http://baike.baidu. com/view/312893.htm

"Wang Daohan". Last modified 30 September 2017. [30.09.2017]. http:// zh.wikipedia.org/wiki/汪道涵

"Wang Yuanhua". Last modified 30 September 2017. [30.09.2017]. http://www. guoxue.com/rw/wangyuanhua/wyh01.htm

"Yang Mingzhao". Last modified 30 September 2017. [30.09.2017]. http://www. guoxue.com/rw/yangmingzhao/ymz01.htm

“Zhou Zhenfu”. Last modified 30 September 2017. [30.09.2017]. http://xbsh.net/ author/1410.html 